\title{
Komposzt illetve mütrágya bioszén kezeléssel mutatott együttes ha- tásának vizsgálata karbonátos homoktalaj nedvességtartalmára és talajlégzésére
}

\author{
${ }^{1}$ Dencsö M., ${ }^{1}$ Tóth E. ${ }^{*},{ }^{1}$ Gelybó Gy., ${ }^{1}$ Kása I., ${ }^{1}$ Horel Á., ${ }^{2}$ RéKÁSI M., ${ }^{3}$ TAKÁCs T., \\ ${ }^{1,4}$ FARKAS CS., ${ }^{1}$ POTYÓ I., ${ }^{2}$ UZINGER N.
}

${ }^{1}$ MTA ATK TAKI Talajfizikai és Vízgazdálkodási Osztály, ${ }^{2}$ MTA ATK TAKI Talajkémiai és Anyagforgalmi Osztály , ${ }^{3}$ MTA ATK TAKI Talajbiológiai Osztály, ${ }^{4}$ NIBIO, Høgskoleveien 7, 1430 Ås, Norvégia

\section{Bevezetés}

A szárazföldi ökoszisztémákban tárolt szénmennyiség jelentős része, akár 80\%a a talajban halmozódik fel (RASMUSSEN et al., 1998). Míg a talajok szénmegkötése lassú folyamat (SCHLESINGER \& LICHTER, 2001; POST \& KWON, 2000), a raktározott szénmennyiség egy része földhasználat váltás, vagy erdőirtások következtében könnyen felszabadulhat (RASMUSSEN et al., 1998). A szén talajban történő hosszútávú megkötésére ígéretes eljárás lehet a bioszén alkalmazása, amellyel potenciálisan nagy mennyiségủ szén raktározható a talajban (LEHMANN et al., 2006). A bioszén olyan stabil anyag, melyet szerves anyagok (föleg növényi maradványok) oxigénszegény, illetve oxigénmentes pirolízise során állítanak elö, és többek között talajjavításra alkalmazható (MOHAN et al., 2006). A bioszenet egyéb, nem szenesedett szerves talajjavító szerekhez - példaként említve növényi hulladékokhoz - hasonlítva megállapítható, hogy a környezeti hatásokkal szemben jóval stabilabb (LEHMANN et al., 2009), hatását hosszabb távon kifejtő anyag. A bioszén alkalmazása széles körben kutatott terület, a klímaváltozás esetleges negatív hatásának mérséklésére szolgáló technológiák egy lehetséges irányvonalaként is ismeretes (Woolf et al. 2010). A bioszén alkalmazásával foglalkozó kutatások egy része a talaj tápanyag tartalmát, kémiai és biológiai tulajdonságait, szénmegkötő képességét és a növényzet vegetatív növekedését vizsgálja (LIANG et al., 2006; AGEGNEHU et al., 2016; KÁSA et al., 2016). A szakirodalom egy jelentős része pedig a bioszén hatásairól nyújt információt a talaj fizikai tulajdonságaira nézve, mint például pórusméret eloszlása, porozitása, aggregátumstabilitása, a talaj térfogattömege, valamint víztartó képessége (ZHANG et al., 2012; SCHIMMELPFENNIG et al., 2014; HERATH, 2013). Bioszén használatával a talaj tápanyagtartalma, vízgazdálkodása javulhat (NGUYEN et al., 2014; SCHIMMELPFENNIG et al., 2014; DOWNIE et al., 2009; CHAN et al., 2007; HARDIE et al., 2014) azáltal, hogy elősegíti az aggregátum-képződést, javítja az aggregátum-stabilitást, így módosítva a talaj pórusainak eloszlását (DownIE et al., 2009; JONES et al., 2011; HARDIE et al., 2014).

A légkör $\mathrm{CO}_{2}$ koncentrációja jelentősen emelkedett az elmúlt évtizedekben, így számos megelőző és problémakezelő lépés ismeretes az újraerdősítéstől kezdve

Postai cím: TóTH EsZTER, MTA ATK TAKI Talajfizikai és Vízgazdálkodási Osztály1022 Budapest Herman Ottó út 15.

E-mail: teszter@rissac.hu 
(IPCC, 2013) a geológiai képződményekbe történő visszapumpálásig (MARCHETTI, 1977). A bioszén kezelés a talaj szénforgalmára is jelentős hatást gyakorol, többek között a talajból származó $\mathrm{CO}_{2}$ fluxust befolyásolja (SUI et al., 2016). A bioszénnel kezelt talaj szénmegkötő képessége elsősorban a hozzá kevert bioszén anyagi minőségétől függ, valamint a talaj fizikai, biokémiai paraméterei is meghatározóak (NGUYEN et al., 2014).

A bioszén alkalmazásával kapcsolatos fenntartások elsősorban a hosszú távon érvényesülő hatással kapcsolatos bizonytalanságok, valamint az alkalmazott dózishoz kapcsolódnak. A bioszén nem megfelelő arányú használata víz és tápanyagforgalmi problémákat okozhat azok megkötése által, valamint a talajban előforduló patogén mikroorganizmusok felszaporodását is okozhatja (KOCSIS \& BIRó, 2015).

Kutatásunkban őrbottyáni homoktalajon vizsgáltuk a bioszén, a mütrágya és komposzt hatását kukorica vetése mellett. Számos publikáció szerint bioszenet komposzttal együttesen alkalmazva kedvezőbb talajjavító, illetve termékenység növelő hatás érhető el, mint mütrágyával kombinálva (SCHULZ \& GLASER, 2012; GLASER et al., 2014; AGEGNEHU et al., 2016). Célkitüzésünk a bioszén P és K mütrágyával kombinált, valamint, a bioszén komposzttal kombinált alkalmazásának összehasonlító vizsgálata volt egy szélsőséges vízháztartású talaj esetén. Kisparcellás kísérlet keretében vizsgáltuk a kezelések hatását a talaj nedvesség-állapotára, valamint a talaj szénkörforgalmában végbemenő rövidtávú változások értékeléséhez a talajlégzés alakulására.

\section{Vizsgálati anyag és módszer}

\section{A mintaterület jellemzése}

Vizsgálatainkat a MTA ATK TAKI örbottyáni kísérleti telepén beállított bioszén kezelési kisparcellás szabadföldi kísérletben végeztük (160 m tszfm, koordináták: É $47^{\circ} 40^{\prime} 22^{\prime}$ ', K $19^{\circ} 14^{\prime} 48^{\prime}$ '). Az egyes kezelések fontosabb talajtani paramétereit az 1. táblázat tartalmazza. A helyszín kiválasztásában szerepet játszott, hogy a talaj nagy vízáteresztő-képességü karbonátos homoktalaj (Arenosols, Cambisols WRB (2006) osztályozás szerint), mely lehetőséget ad a bioszén hatásának tanulmányozására szélsőséges körülmények között. A kezeléseket 2015-ben egy $20 \mathrm{~m} \times 83 \mathrm{~m}$ nagyságú területen állították be ismétlésenként véletlen blokk elrendezésben, a parcellák bruttó területe egyenként $4 \mathrm{~m} \times 5 \mathrm{~m}$ volt, míg a szegélyhatás elkerülése miatt a nettó területe $2 \mathrm{~m} \times 3 \mathrm{~m}$ volt. Az ismétléseket $1 \mathrm{~m}$ széles puffer sáv választotta el egymástól. A kísérletet 2015. április 23-án kezdtük kezelésenként négy ismétlésben bioszén, komposzt és mütrágya kijuttatásával. 2015. április 24-én történt a magágykészítés és az MV277 fajtájú kukorica vetése $70 \mathrm{~cm}$-es sor-, illetve 15 cm tőtáv alkalmazásával.

Az őrbottyáni kísérleti területen a bioszén három különböző dózisának (a 20 cmes szántott rétegre vetítve $0,1 \mathrm{~m} / \mathrm{m} \%, 0,5 \mathrm{~m} / \mathrm{m} \%$ és $1 \mathrm{~m} / \mathrm{m} \%$-os) kijuttatása mellett a kezelések felében 10 t/ha mennyiségben, nagyrészt szennyvíziszap és zöldhulladék alapú BIOMASS Super ASA Organic komposzt kijuttatása történt. A szennyvíziszap komposzt az ASA Magyarország termék minőségü anyaga. A csak bioszenet alkal- 
mazó kezelésekben minden szinten az ajánlott adag fele, $200 \mathrm{~kg} / \mathrm{ha}$ pétisó és 80 kg/ha kálisó került kijuttatásra. Továbbá, egy kezelések nélküli kontroll parcellát is vizsgáltunk. A bioszén és komposzt dózisai a jelen tanulmányban alkalmazott rövidítésekkel együtt az 1. táblázatban láthatók. A kijuttatott anyagok bedolgozása 20 $\mathrm{cm}$ mélységig történt, a kontroll parcella talaján ugyanolyan fizikai bolygatás anyag kijuttatás nélkül valósult meg.

\section{1. táblázat.}

Kísérleti beállítások és talajtulajdonságok (5-10 cm mélységben) az őrbottyáni bioszén hatásvizsgálatban 18 héttel (2015.09.09-én) a bioszén kijuttatását követően az egyes kezelések esetében

\begin{tabular}{|c|c|c|c|c|c|c|}
\hline $\begin{array}{l}\text { A kezelé- } \\
\text { sek rövi- } \\
\text { dítése (1) }\end{array}$ & $\begin{array}{c}\text { Bioszén } \\
\text { dózis [t/ha] } \\
\text { (2) }\end{array}$ & $\begin{array}{c}\text { Kom- } \\
\text { poszt } \\
\text { dózis } \\
\text { [t/ha] (3) }\end{array}$ & $\begin{array}{l}\text { Mütrágya } \\
\text { péti- } \\
\text { só/kálisó } \\
\text { [kg/ha] (4) }\end{array}$ & $\begin{array}{c}\text { Térfogat- } \\
\text { tömeg } \\
{\left[\mathrm{g} / \mathrm{cm}^{3}\right](5)}\end{array}$ & $\begin{array}{c}\mathrm{pH}\left(\mathrm{H}_{2} \mathrm{O}\right) \\
(\mathbf{6})\end{array}$ & $\begin{array}{c}\text { Szerves } \\
\text { szén } \\
{[\mathbf{m} / \mathbf{m} \%]} \\
(7)\end{array}$ \\
\hline $\mathbf{K}$ & 0 & 0 & 0 & $1,45 \pm 0,05$ & $7,69 \pm 0,25$ & $\begin{array}{c}1,483 \pm \\
0,095\end{array}$ \\
\hline BC0,1M & $\begin{array}{c}3(0,1 \\
\mathrm{m} / \mathrm{m} \%)\end{array}$ & 0 & $200 / 80$ & $1,41 \pm 0,06$ & $7,36 \pm 0,48$ & $\begin{array}{c}1,507 \pm \\
0,145\end{array}$ \\
\hline BC0,5M & $\begin{array}{l}15(0,5 \\
\mathrm{m} / \mathrm{m} \%)\end{array}$ & 0 & $200 / 80$ & $1,37 \pm 0,04$ & $7,45 \pm 0,40$ & $\begin{array}{c}1,729 \pm \\
0,052\end{array}$ \\
\hline BC1,0M & $\begin{array}{c}30(1 \\
\mathrm{m} / \mathrm{m} \%)\end{array}$ & 0 & $200 / 80$ & $1,49 \pm 0,03$ & $7,50 \pm 0,43$ & $\begin{array}{c}1,746 \pm \\
0,066\end{array}$ \\
\hline BC0,1K & $\begin{array}{c}3(0,1 \\
\mathrm{m} / \mathrm{m} \%)\end{array}$ & 10 & 0 & n.a. & $7,76 \pm 0,17$ & $\begin{array}{c}1,469 \pm \\
0,157\end{array}$ \\
\hline ВC0,5K & $\begin{array}{l}15(0,5 \\
\mathrm{m} / \mathrm{m} \%)\end{array}$ & 10 & 0 & n.a. & $7,61 \pm 0,12$ & $\begin{array}{c}1,691 \pm \\
0,097\end{array}$ \\
\hline BC1,0K & $\begin{array}{c}30(1 \\
\mathrm{m} / \mathrm{m} \%)\end{array}$ & 10 & 0 & n.a. & $7,62 \pm 0,19$ & $\begin{array}{c}1,891 \pm \\
0,245\end{array}$ \\
\hline
\end{tabular}

A kísérletben alkalmazott bioszén papírgyári iszapból és pelyvából $450-500{ }^{\circ} \mathrm{C}$ on, 20 perces pirolízissel előállított termék volt (Sonnenerde Gmbh, Ausztria). Szemcseméret eloszlása alapján $60 \%$-a $2 \mathrm{~mm}$ alatti tartományba esett. A bioszén $\mathrm{pH}\left(\mathrm{H}_{2} \mathrm{O}\right)$-ja 10,4 volt, szerves széntartalma pedig 60\%-os értékkel bírt.

\section{Szabadföldi mintavételezés és monitoring}

A kezelésekben az $510 \mathrm{~cm}$ es és $2025 \mathrm{~cm}$-es mélységben tíz perces gyakorisággal mértük a talaj nedvességtartalmának és hőmérsékletének változását. A mérésekhez az adott talajra kalibrált 5TM szenzorokat (Decagon Devices Inc, WA, 
USA) használtunk, az adatokat Decagon Em50 típusú adatgyüjtők rögzítették (Decagon Devices Inc, WA, USA).

A talajlégzés $\left(\mathrm{CO}_{2}\right.$ kibocsátás) mérése 2015. augusztus 25-ig, a talajnedvesség és hőmérséklet monitoring pedig 2015. szeptember 8-ig tartott. A talaj $\mathrm{CO}_{2}$ kibocsátását statikus kamrás mintavételi módszerrel, kétheti gyakorisággal vizsgáltuk, kezelésenként öt ismétlésben a kukorica vetésétől a betakarításig. A $20 \mathrm{~cm}$ magas és $10 \mathrm{~cm}$ átmérőjű szeptummal ellátott zárt henger alakú PVC kamrákat a kukorica sorközökbe telepítettük. A talajlevegő mintavétele $10 \mathrm{ml}$-es Hamilton fecskendővel történt. A helyszínen vett levegőmintákat később laboratóriumban, lángionizációs detektorral felszerelt gázkromatográffal (GC 8000, FISONS plc, UK) mértük.

\section{Statisztikai vizsgálatok}

$\mathrm{Az}$ adatok elemzéséhez egytényezős variancia-analízist (one-factor ANOVA) használtunk, ahol a modell függő változója a talajnedvesség, illetve $\mathrm{CO}_{2}$ fluxus, tényezője pedig a kezelés volt. A csoportok páronkénti összehasonlítását a Tukeyféle post hoc-teszttel végeztük. A varianciaelemzés alkalmazhatósági feltételeinek részletes vizsgálatát grafikus módszerekkel, a modell diagnosztikus ábráival állapítottuk meg: QQ-ábra az adatok normalitásának vizsgálatára; szórás-becsült érték ábra a homogenitás, illetve szórások vizsgálatára; és standardizált reziduum-hatóerő ábra a torzítópontok vizsgálatára.

Az adatok összehasonlító statisztikai analízisét R-programmal végeztük ( $\mathrm{R}$ CORE TEAM, 2012). A jelen tanulmányban a statisztikailag szignifikáns különbségeket a $p<0,05$ alatti értékek szerint fogadtuk el.

\section{Vizsgálati eredmények és az eredmények értékelése}

\section{Talajnedvesség-tartalom}

A kísérleti időszak során a vizsgált terület homoktalaján bioszén kezelés (BC) hatására az 5-10 cm-es rétegben szélesebb intervallumban (1-99\% percentilisek távolsága) változott a talajnedvesség az abszolút kontroll környezethez (K) viszonyítva (l. ábra). Tekintettel arra, hogy a talajlégzésre a talaj felsőbb rétegének nedvességtartalma hat döntően (REICHSTEIN et al., 2003), ezért csak a felső 5-10 cm mélységből származó méréseinkre helyeztük a hangsúlyt az eredmények értelmezésében. 


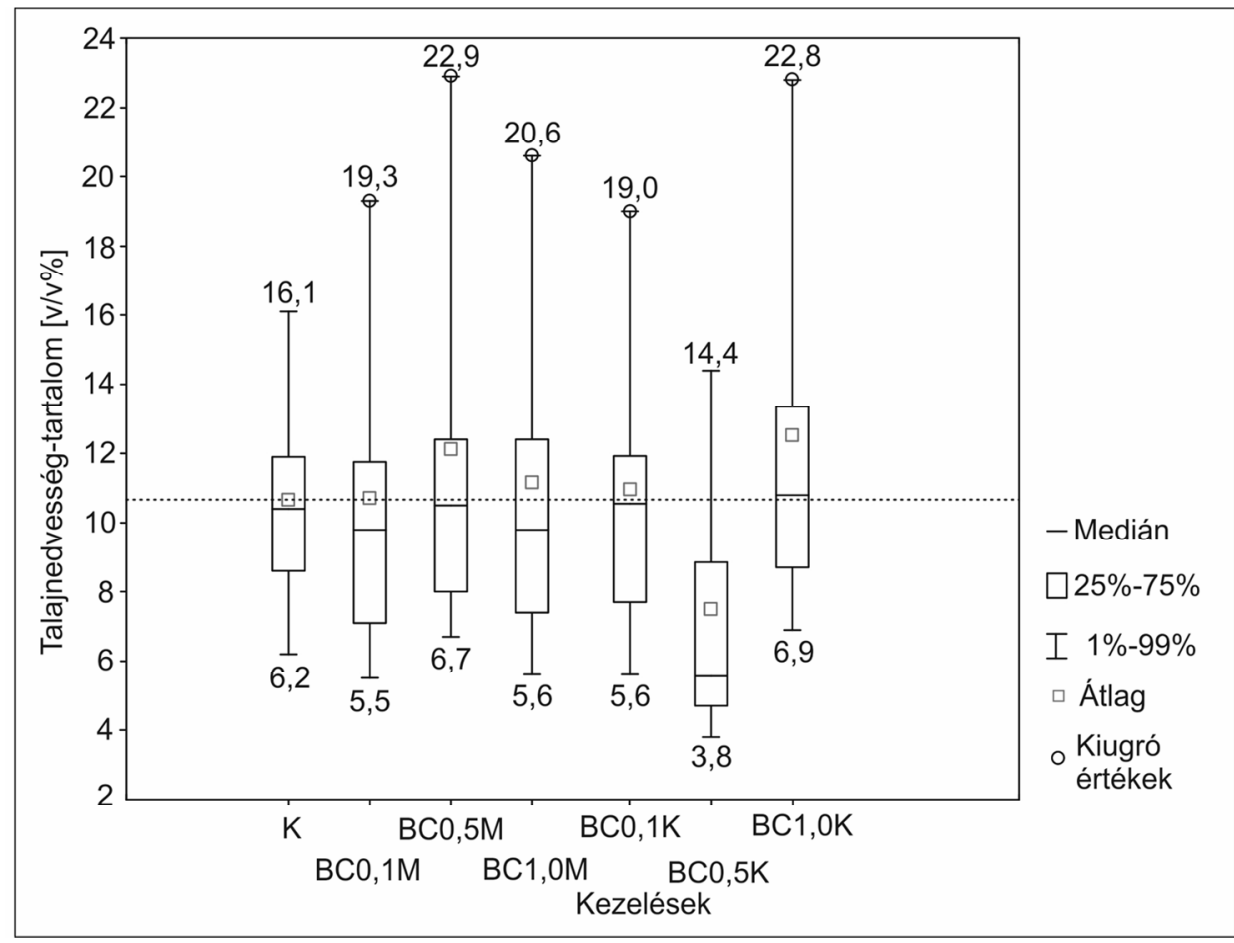

1. ábra.

A vizsgált időszakban, 5-10 cm mélységben mért talajnedvesség-tartalom jellemző statisztikai értékei a különböző kezelésekben. Jelmagyarázat: K: abszolút kontroll; BC a bioszénnel kezelt; míg M és K jelölések a műtrágyát vagy komposztot tartalmazó kezelések. Az ábrán feltüntettük a kezelésekben mért minimum és maximum talajnedvesség értékeket

A talajnedvesség-tartalom a teljes időszakra átlagolva a legnagyobb dózisú $1 \%$ bioszenet tartalmazó komposzttal kombinált kezelés $(\mathrm{BC} 1,0 \mathrm{~K})$ esetében kis mértékben magasabb volt a bioszénnel és mütrágyával kezelt $(\mathrm{BC} 0,1 \mathrm{M} ; \mathrm{BC} 0,5 \mathrm{M}$; $\mathrm{BC} 1,0 \mathrm{M})$, vagy a kontroll parcellához képest (K) (1. ábra). A mütrágyával, illetve komposzttal kevert bioszénkezelések között szignifikáns különbséget találtunk $(\mathrm{p}=0,032)$. A kezeléseket tápanyag típusokon belül összehasonlítva szignifikánsan komposzt-bioszén esetén a $\mathrm{BC} 1,0 \mathrm{~K}$, míg mütrágya- bioszén estén csak a $\mathrm{BC} 0,1 \mathrm{M}$ különbözött a többi kezeléstől $(\mathrm{p}=0,019)$. A BC0,5K kezelés esetén az adatsorban jelentős adathiány keletkezett, az időszak elején a nedvességmérő meghibásodása miatt, így az ebben a kezelésben mért adatokat fenntartásokkal kell kezelni.

$\mathrm{Az}$ abszolút kontrollhoz viszonyítva az $1 \%$ bioszénnel és mütrágyával történő kezelésben $(\mathrm{BC} 1,0 \mathrm{M})$ a talajnedvesség-tartalom értékei a fent ismertetett módon alacsonyabb mediánnal, alacsonyabb $1 \%$-os és magasabb 99\%-os percentilisekkel jellemezhetők, míg az 1\% bioszénnel és komposzttal kombinált kezelés (BC1,0K) rendre magasabb mérőszámokkal rendelkezik. Az abszolút kontrollhoz képest a bioszén és mütrágya kezelésekben magasabb átlagos talajnedvesség-tartalmat mér- 
tünk, azonban a különbség nem számottevő. Hasonló eredményt kaptunk a bioszén és komposzt kezelések esetén, ahol a 0,5\% dózisú bioszén és komposzt kezelésben $(\mathrm{BC} 0,5 \mathrm{~K})$ a talajnedvesség-tartalom átlagosan alacsonyabb volt az összes többi kezeléshez képest, azonban a fent említett adathiány befolyásolhatja ezt az eredményt. LIU et al. (2012) cikkében közölt eredmények szerint a kombinált kezelések (BC 5-20 Mg ha ${ }^{-1}$ és $32,5 \mathrm{Mg} \mathrm{ha}^{-1}$ komposzt) alkalmazásával nőtt jobban a talaj nedvességtartalma a csak bioszenes kezelésekkel egybevetve a kontrollhoz képest. Jelen kutatás eredményei nem támasztják ezt alá, de a legnagyobb dózisú bioszenes komposzt kezelés (BC1,0K) esetében kismértékben hasonló eredményt figyeltünk meg; szignifikáns különbséget azonban nem találtunk a kontrollhoz képest $(\mathrm{p}>0,05)$.

Idö és csapadékesemények függvényében vizsgálva a különböző kezeléseket, csapadékesemény alkalmával a talajnedvesség az abszolút kontrollhoz képest nagyobb mértékben emelkedett meg minden bioszén és mütrágya, valamint bioszén és komposzt kezelésben. A talajnedvesség az $1 \%$ bioszén és komposzt $(\mathrm{BC} 1,0 \mathrm{~K})$ kezelésben nőtt meg a legjobban az abszolút kontroll környezethez képest (2. ábra). Hasonló mértékü nedvesség növekedés volt a $0,5 \%$ bioszenet és mütrágyát tartalmazó $(\mathrm{BC} 0,5 \mathrm{M})$ kezelésben is. A legnagyobb dózisú 1\%-os bioszén és mütrágya kezelésben $(\mathrm{BC} 1,0 \mathrm{M})$ az előzö kettőhöz képest némileg kisebb volt a talajnedvesség növekedése, az alacsonyabb dózisú bioszén kezeléseknél pedig egyformán alakult a talajnedvesség a bioszén és mütrágya $(\mathrm{BC} 0,1 \mathrm{M})$, valamint bioszén és komposzt esetekben egyaránt $(\mathrm{BC} 0,1 \mathrm{~K})$. A kezelés közvetlenül a csapadékesemény alatt és után okoz csak nagyobb talajnedvességet, utána a kiszáradás is gyorsabb, különösen az időszak elején (2. ábra).

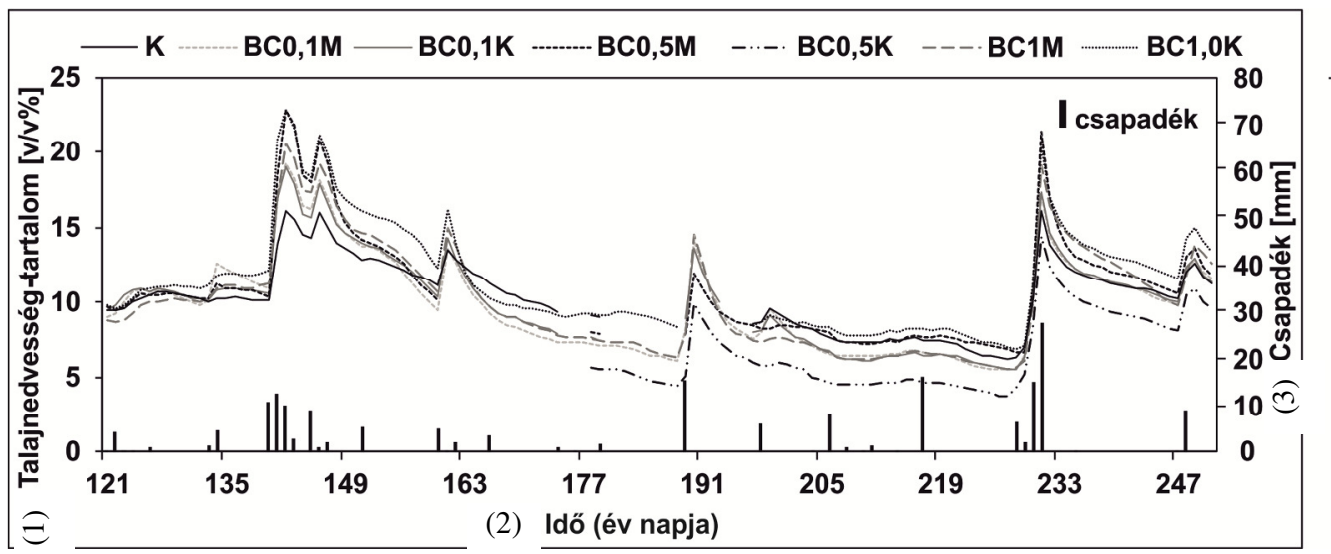

2. ábra.

A talajnedvesség tartalom alakulása a különböző kezelésekben a kísérlet időtartama alatt

Az egyes bioszén és mütrágya, valamint bioszén és komposzt kezelések hatására javuló tendenciát mutató vízháztartás a talaj fizikai tulajdonságainak megváltozásából fakadhatnak. Bioszén alkalmazásával pozitívan lehet befolyásolni a talajok 
fizikai paramétereit, így a hidrológiai jellemzők és a vízvisszatartó képesség is kedvezően alakulhat (MUKHERJEE \& LAL, 2013; YU et al., 2013; BASSO et al., 2013), ezért nagyobb talajnedvesség értékekre lehet számítani.

A szakirodalmi adatok alapján (TRYON, 1948; GLASER et al., 2002; DUGAN et al., 2010; NovAK et al., 2012) homoktalajon jól mérhetően emelkedett a talaj nedvességtartalma bioszén, valamint bioszén és komposzt együttes alkalmazásának hatására. Jelen tanulmányban a legnagyobb dózisú $1 \%$ bioszenes és komposztos (BC1,0K) kezelésben volt kisebb mértékủ, pozitív eltérés az abszolút kontroll környezethez képest, a bioszén és mütrágya kezelések közül pedig a 0,5\%-os $(\mathrm{BC} 0,5 \mathrm{M})$ parcella talajnedvessége mutatta a legnagyobb pozitív eltérést.

\section{Szerves szén mennyiségének alakulása}

A talaj szerves széntartalmának alakulását az egyes kezelések esetén az 1. táblázat szemlélteti. A bioszén kezelés hatására a talaj szerves szén tartalma a kontroll kezelésben megfigyelt $1,483 \pm 0,095 \mathrm{~m} / \mathrm{m} \%$-hoz képest növekedett, a legnagyobb, $1 \%$ os bioszénnel kevert komposzt kezelés esetében (BC1,0K) 1,891 $\pm 0,245 \mathrm{~m} / \mathrm{m} \%$ értéket ért el. A talajba bioszén formájában kijuttatott szerves szén a bomlási folyamatoknak ellenálló, így közvetlenül nem járulhat hozzá a talajlégzéshez. Azonban, ha az 1,483\% szerves széntartalmat és a megadott térfogattömeget használjuk, a 30/15/3 tonna bioszénnek megfelelően a szerves széntartalom értékek 1,767/1,625/1,511\%-ra módosulnak a talajba keverés során, a komposzt nélkül. A táblázatban bemutatott mért 1,746/1,729/1,507\% szervesszén értékek alátámasztják, hogy a bioszén nem bomlott le, a vizsgált időtartam folyamán, így nem keletkezett belöle $\mathrm{CO}_{2}$.

\section{Talajlégzés $\left(\mathrm{CO}_{2}\right.$ kibocsátás)}

A bioszén széles körü alkalmazási lehetőségének és az alkalmazás környezeti hatásainak felmérésében fontos megvizsgálni a talajlégzést.

A talaj mikrobiális eredetủ $\mathrm{CO}_{2}$ kibocsátását a talaj szerves széntartalma, valamint az egyik elsődleges környezeti változó, a talaj nedvességtartalma erősen befolyásolja (DAVIDSON et al., 2000; TANG et al., 2006). A talaj nedvességtartalmát az előzö fejezetben tárgyaltuk. A talaj nedvességforgalmára gyakorolt hatáson, a növények növekedésére gyakorolt hatásán keresztül a gyökérlégzést módosíthatja indirekt módon, valamint a mikrobiális biomassza nagyságát és aktivitását is befolyásolhatja, melyek változása a talajlégzésre is hatással van (KoCsIS \& BIRÓ, 2015). A 3. ábra az abszolút kontroll, valamint a különböző dózisú bioszén és mütrágya kezelésekben mért $\mathrm{CO}_{2}$ kibocsátás értékeket mutatja. Csak egyes kezeléseknél volt jól megfigyelhető különbség az abszolút kontroll és a bioszénkezelések között a talajlégzésben (3. ábra). A különböző bioszéndózisok hatását vizsgálva szignifikáns eltérést a talajlégzésben a kezelések között nem találtunk ( $>00,05$; ANOVA). A vegetációs időszakban összesen kilenc mintavételi időpontban történt vizsgálat. A legmagasabb $1 \%$-os bioszén és mütrágya kezelés $(\mathrm{BC} 1,0 \mathrm{M})$, valamint az abszolút kontroll között a 133.; 148.; 161. és 237. napokon, a 0,5\% bioszénnel kezelt parcel- 
la (BC0,5M) és az abszolút kontroll között pedig a 133., a 148., a 189. és a 237. napokon volt nagymértékü eltérés a talajlégzésben. Az egész idősorra vetítve, a statisztikai elemzések alapján a kezelések (komposzt illetve mütrágyával kombinált bioszén kezelések) közötti különbség talajlégzés terén szignifikáns volt ( $\mathrm{p}=0,0012$; ANOVA). Összességében elmondható, hogy a mérési időpontok 44\%-ában a 0,5\% bioszénnel kezelt parcellában (BC0,5M) mért talajlégzés tért el legjobban az abszolút kontroll parcellától, valamint a mérési napokat vizsgálva az esetek 56\%-ában ennél a kezelésnél volt a legnagyobb a talajlégzés a többi bioszén és műtrágya kezeléshez (BC0,1M és $\mathrm{BC} 1,0 \mathrm{M})$ képest. A bioszén és mütrágya kezelés talajnedvességtartalmon keresztül kifejtett indirekt hatását alátámaszthatja, hogy ennél a kezelésnél kaptuk a legnagyobb korrelációs együtthatót a talajlégzés és a talajnedveség között $\left(R^{2}=0,44\right)$, valamint az itt mérhető talajnedvesség tér el legjobban az abszolút kontrollhoz képest. Ez az eredmény arra utal, hogy a kísérlet során a talajnedvesség-tartalom erősen limitálta a talajlégzést.

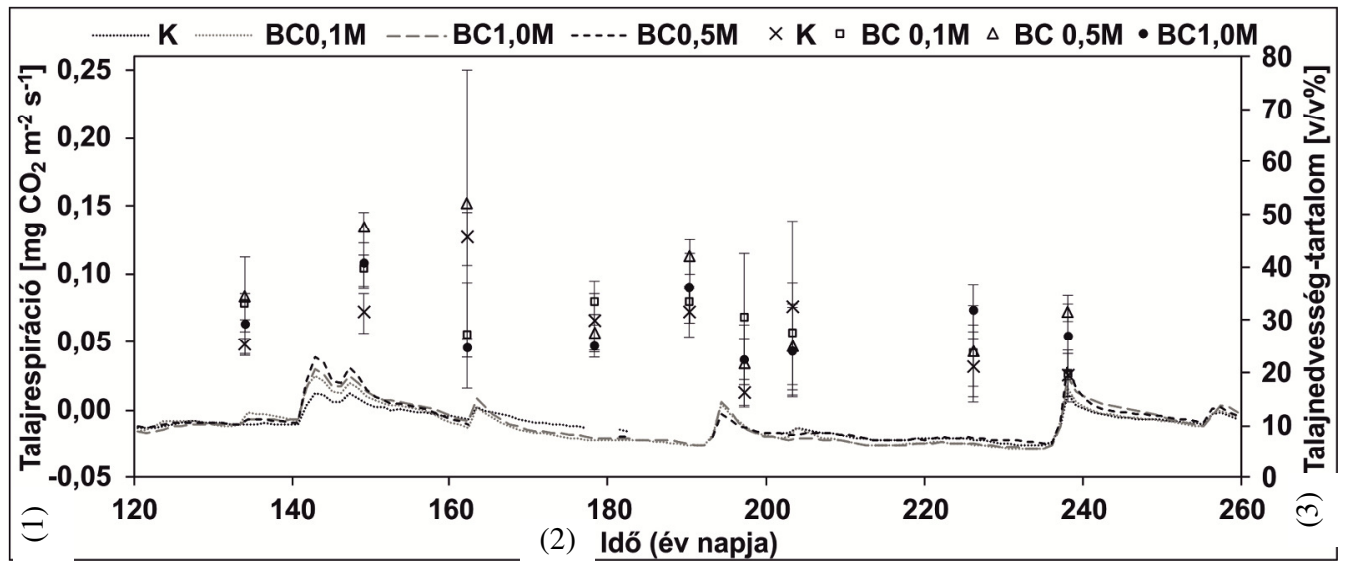

3. ábra.

A talajrespiráció azaz talajlégzés, valamint az 5-10 cm mélységben mért talajnedvesség alakulása mütrágyás kezelés esetén

A kezelések esetében látható, hogy csapadékesemények után (148.; 162.; 196.; 237. napon) a $\mathrm{BC} 0,1 \mathrm{~K}$ bioszén és komposztos kezelésben, hosszabban tartó szárazabb időszak után pedig a 0,5\% bioszén és komposzt (BC0,5K) (133.; 177.; 189. napon), illetve az $1 \%$ bioszén és komposzt kezelésekben (BC1,0K) (202.; 225. napon) volt a legnagyobb a talajlégzés (4. ábra).

Adataink alapján nem találtunk egyértelmü összefüggést a talajlégzés és különböző bioszén dózisok között, eredményeink alapján elmondható, hogy a bioszén kijuttatása nem növelte a talaj $\mathrm{CO}_{2}$ kibocsátását. Habár a bioszén és mütrágya, valamint bioszén és komposzt kezeléseket összevetve összességében a vizsgált időszak 78\%-ában a komposztos kezelések esetében nagyobb volt a talajlégzés, ezek az eltérések a teljes időszakra számítva nem voltak szignifikánsak $(p>0,05)$. Az 
egyes mintavételi időpontokat külön vizsgálva a talajlégzést a komposzttal kezelt kezelések többsége esetén szignifikánsan különbözött a kontroll kezeléstöl.

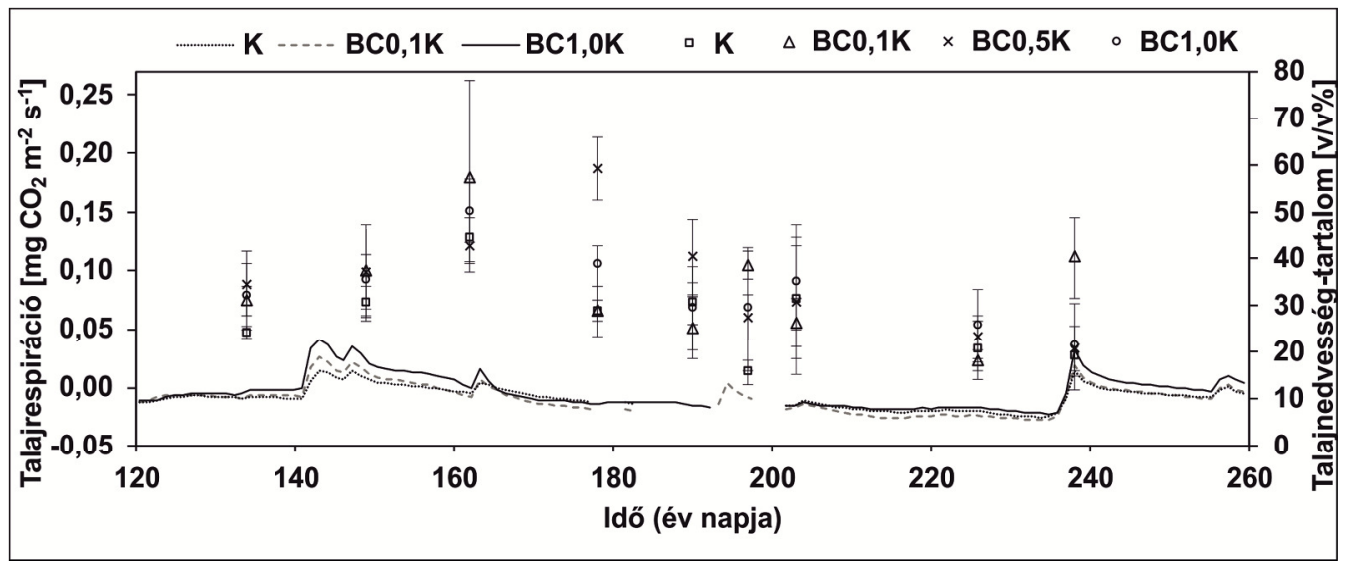

4. ábra.

A talajrespiráció, azaz talajlégzés valamint az 5-10 cm mélységben mért talajnedvesség alakulása komposztos kezelések esetén

A bioszén potenciálisan befolyásolhatja a talaj szervesanyag tartalmának lebomlását (NGUYEN et al. 2014). LAIRD et al. (2010) eredményei alapján a bioszenet alkalmazva a szerves széntartalom akár 69\%-kal is megnőhet, ezzel is alátámasztva, hogy a bioszén a mezőgazdaságban igen jól hasznosítható talajjavító anyag. Kísérletünkben a legnagyobb dózisú $1 \%$ bioszén és komposzt kezelés $(\mathrm{BC} 1,0 \mathrm{~K})$ esetében ennél némileg alacsonyabb, 27\%-os emelkedés volt megfigyelhető (1. táblázat). Ez a különbség azonban a kísérlet rövid idötartama miatt nem a talaj szerves széntartalmának lebomlási folyamatainak változását mutatja, sokkal inkább a bioszén hozzáadott széntartalmának tulajdonítható.

A bemutatott eredmények egy rövidtávú monitoringból származnak, a bioszén hosszútávú hatásáról jelenleg nemzetközi szinten is csak kevés tanulmány áll rendelkezésre. Kiegészítő növényvizsgálatok és talajbiológiai vizsgálatok, izotópos vizsgálatok a talajlégzés autotróf és heterotróf összetevőinek elkülönítésére, és a szántóföldi vízkapacitás változásának mérése szükségesek ahhoz, hogy a bioszén kezelések hatásáról megalapozottabb véleményt tudjunk mondani.

\section{Összefoglalás}

A talajok tulajdonságainak javítása céljából végzett bioszénnel történő kezelések hatása a különböző fizikai, kémiai és biológiai tulajdonságú talajok esetében még nem teljesen ismert. Kísérleteinket homoktalajon végeztük az MTA ATK TAKI Örbottyánban lévő kísérleti telepén, ahol kukoricát vetettek. Hét kezelést vizsgáltunk, négy ismétlésben. Három esetben a talaj különböző dózisban bioszenet és 
konstans dózisú mütrágyát tartalmazott $(0,1 \mathrm{~m} / \mathrm{m} \% ; 0,5 \mathrm{~m} / \mathrm{m} \% ; 1 \mathrm{~m} / \mathrm{m} \%$; jelölésük $\mathrm{BC} 0,1 \mathrm{M} ; \mathrm{BC} 0,5 \mathrm{M} ; \mathrm{BC} 1,0 \mathrm{M})$, három esetben pedig a fent említett bioszén dózisokat egységesen 10 t/ha komposzttal egészítettuik ki (BC0,1K; BC0,5K; BC1,0K). Ezek mellett pedig kialakítottunk egy bioszén és komposzt mentes abszolút kontroll $(\mathrm{K})$ kezelést is. Kutatásunk során talajszondákkal monitoroztuk a talajnedvességtartalmának alakulását, valamint statikus kamrás mintavételi eljárással a talajlégzést is mértük a kezelésekben.

A talajnedvesség éves átlagát nézve $1 \%$ bioszénnel és komposzttal kezelt parcella esetében a talaj nedvességtartalma nem szignifikáns mértékben növekedett a bioszén és komposzt mentes abszolút kontroll környezethez képest. Csapadékesemények alkalmával az $1 \%$ bioszenet és komposztot tartalmazó parcellában nőtt meg legjobban a talajnedvesség, illetve hasonlóan alakult a nedvességtartalom a 0,5\% bioszénnel kezelt mütrágyás parcellában is. Csapadékesemények után az összes bioszenet és mütrágyát, illetve bioszenet és komposztot tartalmazó parcellában gyorsabban száradt ki a talaj a kontrollhoz képest. A csapadékban szegényebb, szárazabb időszak alkalmával egyedül az $1 \%$ bioszenet és komposztot tartalmazó kezelés talajnedvessége volt magasabb a kontrollhoz képest, a 0,5\% bioszénnel és mütrágyával kezelt, komposzt mentes esetben a nedvesség hasonlóan alakult a kontrollhoz viszonyítva, az összes többi esetben jóval az alatt maradtak az értékek.

Összességében megállapítható, hogy a komposztot tartalmazó talajok érzékenyebben reagáltak a csapadékra, a legjobb vízgazdálkodást az $1 \%$ bioszén és komposzt kezelés esetében értük el. Önmagában a bioszén nagy mennyiségü $(1,0$ m/m\%) adagolása nem volt egyértelmüen talajnedvesség-növelö hatású.

A bioszén szén-dioxid forgalomra történő hatását a talajlégzés mérésével vizsgáltuk. A bioszénnel, valamint mütrágyával kezelt és a kontroll kezelések között csak néhány esetben volt különbség. A komposzttal kevert bioszén kezelések alkalmával hasonló eredményre jutottunk, mint a mütrágyával kevert bioszén esetében. Eredményeink alapján arra következtethetünk, hogy a talajlégzés nem függött a bioszén dózisától. A bioszén talajlégzésre gyakorolt hatása közvetett módon, a talajnedvesség befolyásolásán keresztül valósul meg, mivel bioszenet alkalmazva bizonyos esetekben a talajnedvesség emelkedett a kontrollhoz képest, ekkor a talajlégzés ugyancsak magasabb lett, amely jelenség a komposzttal kezelt esetekben jól megfigyelhető volt.

\footnotetext{
Ábrajegyzék

1. táblázat: Kísérleti beállítások és talajtulajdonságok (5-10 cm mélységben) az őrbottyáni bioszén hatásvizsgálatban 18 héttel (2015.09.09-én) a bioszén kijuttatását követően az egyes kezelések esetében

1. ábra: A vizsgált időszakban, $5-10 \mathrm{~cm}$ mélységben mért talajnedvességtartalom jellemzö statisztikai értékei a különböző kezelésekben. Jelmagyarázat: K: abszolút kontroll; $\mathrm{BC}$ a bioszénnel kezelt; míg $\mathrm{M}$ és $\mathrm{K}$ jelölések a mütrágyát vagy komposztot tartalmazó kezelések. Az ábrán feltüntettük a kezelésekben mért minimum és maximum talajnedvesség értékeket
} 
2. ábra: A talajnedvesség tartalom alakulása a különböző kezelésekben a kísérlet időtartama alatt

3. ábra: A talajrespiráció, azaz talajlégzés valamint az $5-10 \mathrm{~cm}$ mélységben mért taljnedvesség alakulása mütrágyás kezelés esetén

4. ábra: A talajrespiráció, azaz talajlégzés valamint az 5-10 cm mélységben mért taljnedvesség alakulása komposztos kezelések esetén

Munkánkat a Norvég Finanszírozási Mechanizmus 2009-2014, HU09-0029-A12013, az OTKA K-101065 és a K-104816 projekt, valamint az OTKA PD116084 és PD116157 kutatási projektek támogatták.

Kulcsszavak: bioszén, talajszerkezet, talajnedvesség, talajjavítás, $\mathrm{CO}_{2}$

\section{Irodalom}

Agegnehu, G., Bass, A. M., Nelson, P. N., BIRD, M. I. 2016. Benefits of Biochar, Compost and Biochar-compost for Soil Quality, Maize Yield and Greenhouse Gas Emissions in a Tropical Agricultural Soil. Science of The Total Environment 543. 295-306.

Basso, A. S., Miguez, F. E., Laird, D., Horton, A. R.,Westgate, M. 2013. Assessing Potential of Biochar for Increasing Water-Holding Capacity of Sandy Soils. GCB Bioenergy 5. (2) 132-143.

Chan, K. Y., Van Zwieten, L., Meszaros, I., Downie, A., Joseph, S. 2007. Agronomic Values of Greenwaste Biochar as a Soil Amendment. Australian Journal of Soil Research 45. (8) 629-634.

Davidson, E., Verchot, L., Cattanio, J., ACKerman, I., CARValho, J. 2000. Effects of Soil Water Content on Soil Respiration in Forests and Cattle Pastures of Eastern Amazonia. Biogeochemistry 48. 53-69.

Downie, A., Crosky, A., Munroe, P. 2009. Physical Properties of Biochar. J. LEHMANN and STEPHEN J. [szerk.] Biochar for Environmental Management: Science and Technology. 13-29 Earthscan kiadó, London. - 448 oldal.

Dugan, E., A. Verhoef, S. Robinson, Sohi, S. 2010. Bio-Char from Sawdust, Maize Stover and Charcoal: Impact on Water Holding Capacities of Three Soils from Ghana. 19th World Congress of Soil Science, Soil Solutions for a Change World, August 9-12.

Glaser, B., J. Lehmann, W. ZeCh, 2002. Ameliorating Physical and Chemical Properties of Highly Weathered Soils in the Tropics with Charcoal - A Review. Biology and Fertility of Soils 35. (4) 219-230.

Hardie, M., Clothier, B., Bound, S., Oliver, G. ,Close, D. 2014. Does Biochar Influence Soil Physical Properties and Soil Water Availability? Plant Soil 376, 347-361. 
Herath, H. M. S. K., M. CAMPS-ARBESTAIN, M. HedLEy. 2013. Effect of Biochar on Soil Physical Properties in Two Contrasting Soils: An Alfisol and an Andisol. Geoderma 209-210. 188-197.

IPCC. 2013., Ciais, P., SAbine, C., Bala, G., BopP, L., Brovkin, V., CANAdell, J., Chhabra, A., DeFries, R., Galloway, J., Heimann, M., Jones, C., Le Quéré, C., Myneni, R. B., PiaO, S.,Thornton, P. 2013. Carbon and Other Biogeochemical Cycles. In: Climate Change 2013: The Physical Science Basis. Contribution of Working Group I to the Fifth Assessment Report of the Intergovernmental Panel on Climate Change [Stocker, T.F., Qin, D., Plattner, G.-K., Tignor, M., Allen, S. K., Boschung, J., Nauels, A., Xia, Y., Bex, V., $\begin{array}{lllll}\text { Midgley, } & \text { P.M. } & \text { [szerk]]. } & \text { 6.5.2.1. fejezet } & \text { 547. }\end{array}$ https://www.ipcc.ch/pdf/assessmentreport/ar5/wg1/WG1AR5 Chapter06_FINA L.pdf

Jones, D. L., Murphy, D. V., Khalid, M., Ahmad, W., EdWards-Jones, G., DELUCA, T. H. 2011. Short-term Biochar-induced Increase in Soil $\mathrm{CO}_{2}$ Release is Both Biotically and Abiotically Mediated. Soil Biology and Biochemistry 43. (8). 1723-1731.

KÁSA I., MOLNÁr S., HoRel Á. 2016. A Hőmérséklet és a Bioszén Típusának, valamint Mennyiségének Hatása a Talaj Nettó Nitrifikációjára. Agrokémia és Talajtan 65. 297-311.

KoCSIS T., BIRÓ B. 2015. Bioszén hatása a talaj-növény-mikróba rendszerre: elönyök és aggályok — Szemle. Agrokémia és Talajtan 64. 257-272.

Laird, D. A., Fleming, P., Davis, D. D., Horton, R., Wang, B., Karlen, D. L. 2010. Impact of Biochar Amendments on the Quality of a Typical Midwestern Agricultural Soil. Geoderma 158. (3-4). 443-449.

LEHMANN, J., GAUNT, J., RondON, M. 2006. Bio-Char Sequestration in Terrestrial Ecosystems - A Review. Mitigation and Adaptation Strategies for Global Change 11. (2) 403-427.

Lehmann, J., CZIMCZIK, C., LAIRD, D., SoHI, S. 2009. Biochar for Environmental Management: Science and Technology Lehmann, J., Joseph, S. [szerk]. 11. fejezet: Stability of Biochar in Soil. 183. oldal.

Liang, B., LehmanN, J., Solomon, D., KinYangi, J., Grossman, J., O’Neill, B., SkJemstad, J. O., Thies, J., LuizaO, F. J., Petersen, J., NeVes., E. G. 2006. Black Carbon Increases Cation Exchange Capacity in Soils. Soil Science Society of America Journal 70. (5) 1719-1730.

Liu, J., Schulz, H., Brandl, S., MiehtKe, H., Huwe, B., Glaser, B. 2012. Shortterm Effect of Biochar and Compost on Soil Fertility and Water Status of a Dystric Cambisol in NE Germany under Field Conditions. Journal of Plant Nutrition and Soil Science 175. (5) 698-707.

MARCHETTI, C.1977. On geo-engineering and $\mathrm{CO}_{2}$ problem. Climatic Change. 1. 59-68.

Mohan, D., Pittman, C. U., JR., Steele, P. H. 2006. Pyrolysis of Wood/Biomass for Bio-oil: A Critical Review. Energy Fuels 20. 848-889.

MukHerJee, A., LAL., R. 2013. Biochar Impacts on Soil Physical Properties and Greenhouse Gas Emissions. Agronomy 3. (2) 313-339. 
Nguyen, B. T., Koide, R. T., Dell, C., Skinner, H., Adler, P. R., NoRd, A. 2014. Turnover of Soil Carbon following Addition of Switchgrass-derived Biochar to Four Soils. Soil Science Society of America Journal 78. (2) 531-537.

NovaK, J.M., Busscher, W.J., Watts, D.W., AMONETte, J.E., IPPOlito, J. A., Lima, I. M., GASKIN, J., DAS, K. C., STEInER, C., AHMEDNA, M., ReHRAH, D., SCHOMBERG, H. 2012. Biochars Impact on Soil-Moisture Storage in an Ultisol and Two Aridisols. Soil Science. 177. (5)310-320.

Post, W. M., KwON, K. C. 2000. Soil Carbon Sequestration and Land-Use Change: Processes and Potential. Global Change Biology 6. (3) 317-327.

Rasmussen, P. E., Goulding, K. W. T.,Brown, J. R., Grace, P. R., Janzen, H. H., Ko, M. 1998. Long-Term Agroecosystem Experiments: Assessing Agricultural Sustainability and Global Change. Science. 282. 893-896.

$\mathrm{R}$ CORE TEAM 2012. A language and environment for statistical computing. $\mathrm{R}$ Foundation for Statistical Computing, Vienna, Austria. ISBN 3-900051-07-0.

Schimmelpfennig, S., Müller, C., GrÜNhage, L., Koch, C., Kammann, C. 2014. Biochar, Hydrochar and Uncarbonized Feedstock Application to Permanent grassland - Effects on Greenhouse Gas Emissions and Plant Growth. Agriculture, Ecosystems \& Environment 191. 39-52.

SCHLESINGER, W. H., LichTER, J. 2001. Limited Carbon Storage in Soil and Litter of Experimental Forest Plots under Increased Atmospheric $\mathrm{CO}_{2}$. Nature 411. (6836) 466-469.

Schulz, H., Glaser, B. 2012. Effects of Biochar Compared to Organic and Inorganic Fertilizers on Soil Quality and Plant Growth in a Greenhouse Experiment. Journal of Plant Nutrition and Soil Science 175. 410-422.

Solaiman, M. Z., Blackwell, P. Aвbott, L. K., Storer, P. 2010. Direct and Residual Effect of Biochar Application on Mycorrhizal Root Colonisation, Growth and Nutrition of Wheat. Australian Journal of Soil Research 48. 546554.

Sui, Y., GaO, J., LiU, C., Zhang, W., Lan, Y., Li, S., Meng, J., Xu, Z.,. Tang, L. 2016. Interactive Effects of Straw-derived Biochar and N Fertilization on Soil C Storage and Rice Productivity in Rice Paddies of Northeast China. Science of The Total Environment 544. 203-210.

TANG, X. L., Zhou, G. Y., LIU, S. G., Zhang, D. Q., LiU, S. Z. , LI, J., Zhou, C. Y. 2006. Dependence of Soil Respiration on Soil Temperature and Soil Moisture in Successional Forests in Southern China. Journal of Integrative Plant Biology 48. (6) 654-663.

TrYON, A. E. H. 1948. Effect of Charcoal on Certain Physical, Chemical, and Biological Properties of Forest Soils. Ecological Society of America, Division of Forestry 18. (1) 81-115.

Woolf, D., Amonette, J., E., STReEt-Perrott, A., Lehmann, J., JosePh, S. 2010. Sustainable Biochar to Mitigate Global Climate Change. Nature Communications 1. (5) 1-9.

YU, O-Y., RAICHLE, B., SINK, S. 2013. Impact of Biochar on the Water Holding Capacity of Loamy Sand Soil. International Journal of Energy and Environmental Engineering 4. (1) 44. 
Zhang, A., LiU, Y., Pan, G., Hussain, Q., Li, L., Zheng, J., Zhang, X. 2012. Effect of Biochar Amendment on Maize Yield and Greenhouse Gas Emissions from a Soil Organic Carbon Poor Calcareous Loamy Soil from Central China Plain. Plant and Soil 351. (1-2) 263-275.

\title{
Changes in the moisture content and respiration of a calcareous sandy soil after combined treatment with biochar and compost or mineral fertiliser
}

\author{
${ }^{1}$ M. Dencsö, ${ }^{1}$ E. TÓth ${ }^{*},{ }^{1}$ G. Gelybó, ${ }^{1}$ I. KÁsA, Á. ${ }^{1}$ Horel,${ }^{2}$ M. RÉKÁSI, ${ }^{3}$ T. \\ TAKÁCS, ${ }^{1,4}$ C. FARKAS, ${ }^{1}$ I. POTYÓ and N. ${ }^{2}$ UZINGER \\ ${ }^{1}$ Department of Soil Physics and Water Management, ${ }^{2}$ Department of Soil \\ Chemistry and Turnover, ${ }^{3}$ Department of Soil Biology, Institute for Soil Science \\ and Agricultural Chemistry, Centre for Agricultural Research, Hungarian Acad- \\ emy of Sciences, ${ }^{4} \mathrm{NIBIO}$, Norway
}

\section{Summary}

The main purpose of this work was to examine the use of biochar amended with organic or inorganic nutrients to improve soil quality and to reduce the emission of greenhouse gases (GHG), especially $\mathrm{CO}_{2}$, from agricultural land.

There are still gaps in our knowledge of how soils with different physical, chemical and biological properties are affected by the biochar added to improve soil properties. Experiments were performed on a sandy soil at the experimental station of the Institute for Soil Science and Agricultural Chemistry (MTA ATK) at Örbottyán, where maize was sown with seven treatments in four replications. In three of the treatments the soil was treated with various doses of biochar $(0.1,0.5$ and 1.0 $\mathrm{m} / \mathrm{m} \%$ ) and a constant rate of mineral fertiliser (designated as $\mathrm{BC} 0.1 \mathrm{M}, \mathrm{BC} 0.5 \mathrm{M}$ and $\mathrm{BC} 1.0 \mathrm{M}$, respectively), while in three others the above doses of biochar were supplemented with a uniform $10 \mathrm{t} / \mathrm{ha}$ rate of compost (designated as $\mathrm{BC} 0.1 \mathrm{~K}$, $\mathrm{BC} 0.5 \mathrm{~K}$ and $\mathrm{BC} 1.0 \mathrm{~K})$. The $7^{\text {th }}$ treatment was the absolute control, given no biochar fertiliser or compost (designated as $\mathrm{K}$ ). Soil sensors were used to monitor trends in soil moisture content, while the $\mathrm{CO}_{2}$ emission of the soil was recorded in each treatment using samples taken from a static chamber.

No significant increase in the mean annual soil moisture content was recorded in the plot treated with $1 \%$ biochar + compost compared with the absolute control. In response to rainfall events, the soil moisture content rose to the greatest extent in the plot given $1 \%$ biochar + compost, though similar values were recorded in the plot treated with $0.5 \%$ biochar + mineral fertiliser.

The soil in all the treated plots dried out more quickly after rainfall events than that of the absolute control. During drier periods with little rainfall, the soil moisture content was only greater than in the control in the $\mathrm{BC} 1.0 \mathrm{~K}$ treatment, while that 
in the $\mathrm{BC} 0.5 \mathrm{M}$ treatment was similar to the control value. In all the other treatments the moisture contents were considerably lower.

All in all, soils containing compost responded more sensitively to rainfall, with the best water management in the $\mathrm{BC} 1.0 \mathrm{~K}$ treatment. When applied alone, the highest rate of biochar $(1.0 \mathrm{~m} / \mathrm{m} \%)$ had no clear soil moisture-increasing effect.

The effect of biochar on carbon dioxide turnover was investigated by measuring soil respiration. Differences between the biochar + mineral fertiliser or compost treatments and the control were only recorded in a few cases, so it can be concluded that $\mathrm{CO}_{2}$ emission did not depend on the biochar dose. The effect of biochar on soil respiration is exerted indirectly through its influence on soil moisture content; in cases where the addition of biochar led to a rise in soil moisture content compared to the control, higher values of $\mathrm{CO}_{2}$ emission were also recorded. This was especially pronounced when biochar was applied with compost.

Key words: biochar, soil structure, soil moisture, soil amelioration, $\mathrm{CO}_{2}$

Table 1. Experimental treatments and soil properties (at a depth of 5-10 cm) in the various treatments, 18 weeks after the application of biochar (Örbottyán, 9 September 2015). (1) Treatment code. (2) Biochar dose, t/ha. (3) Compost dose, t/ha. (4) Mineral fertiliser (calcium ammonium nitrate/potassium chloride), $\mathrm{kg} / \mathrm{ha}$. (5) Bulk density, $\mathrm{g} / \mathrm{cm}^{3}$. (6) $\mathrm{pH}\left(\mathrm{H}_{2} \mathrm{O}\right)$. (7) Organic carbon, $\mathrm{m} / \mathrm{m} \%$.

Figure 1. Descriptive statistics of the soil moisture content at a depth of 5-10 $\mathrm{cm}$ in the individual treatments during the experimental period. (1) Soil moisture content, v/v\%. (2) Treatments. a) Median; b) Mean; c) Outstanding values. Treatment codes: K: Absolute control; BC0.1M, BC0.5M, BC1.0M: 0.1, 0.5, 1.0\% biochar + mineral fertiliser; $\mathrm{BC} 0.1 \mathrm{~K}, \mathrm{BC} 0.5 \mathrm{~K}, \mathrm{BC} 1.0 \mathrm{~K}: 0.1,0.5,1.0 \%$ biochar + compost. Note: The minimum and maximum soil moisture values recorded in the treatments are shown in the figure.

Figure 2. Changes in soil moisture content in the individual treatments during the experimental period. (1) Soil moisture content, v/v\%. (2) Time (day of the year). (3) Rainfall, mm. For treatment codes, see Figure 1.

Figure 3. Changes in soil respiration and the soil moisture content at a depth of $5-10 \mathrm{~cm}$ in the mineral fertiliser treatments. (1) Soil respiration, $\mathrm{mg} \mathrm{CO}_{2} \mathrm{~m}^{-2} \mathrm{~s}^{-1}$. (2) Time (day of the year). (3) Soil moisture content, v/v\%. For treatment codes, see Figure 1. Note: Lines indicate soil moisture content; symbols indicate soil $\mathrm{CO}_{2}$ emission.

Figure 4. Changes in soil respiration and the soil moisture content at a depth of $5-10 \mathrm{~cm}$ in the compost treatments. (1)-(3) and Note: see Figure 3. For treatment codes, see Figure 1. 